\title{
Keutel syndrome
}

\author{
INSERM
}

\section{Source}

INSERM. (1999). Orphanet: an online rare disease and orphan drug data base. Keutel syndrome. ORPHA:85202

Keutel syndrome is characterised by diffuse cartilage calcification, brachytelephalang ism, peripheral pulmonary artery stenoses and facial dysmorphism. 